\title{
The Effect of Acetazolamide on Cerebral Blood Flow and Oxygen Utilization in the Rhesus Monkey
}

\author{
B. E. LAUX and M. E. RaICHLE, Division of Radiation Sciences, Mallinckrodt \\ Institute of Radiology, Department of Neurology, Washington University \\ School of Medicine, St. Louis, Missouri 63110
}

\begin{abstract}
A в S T R A C T The brain is critically dependent for its moment to moment function and survival on an adequate supply of oxygen. The enzyme carbonic anhydrase (EC 4.2.1.1) may play an important role in oxygen delivery to brain tissue by facilitating the hydration of metabolically produced carbon dioxide in erythrocytes in brain capillaries, thus permitting the Bohr effect to occur. We examined the effect of $30 \mathrm{mg} / \mathrm{kg}$ i.v. acetazolamide, a potent inhibitor of carbonic anhydrase, upon cerebral blood flow and oxygen consumption in lightly anesthetized, passively ventilated rhesus monkeys. Cerebral blood flow and oxygen consumption were measured with oxygen-15-labeled water and oxygen-15labeled oxyhemoglobin, respectively, injected into the internal carotid artery and monitored externally. Acetazolamide produced an immediate and significant increase in cerebral blood flow (from a mean of 64.7 to $83.8 \mathrm{ml} / 100 \mathrm{~g}$ per $\mathrm{min}$ ), an increase in arterial carbon dioxide tension (from a mean of 40.7 to 47.5 torr), and a decrease in cerebral oxygen consumption (from a mean of 4.16 to $2.82 \mathrm{ml} / 100 \mathrm{~g}$ per min). Because the change in cerebral oxygen consumption occurred within minutes of the administration of acetazolamide, we believe that this effect probably was not due to a direct action on brain cells but was achieved by an interference with oxygen unloading in brain capillaries. A resultant tissue hypoxia might well explain part of the observed increase in cerebral blood flow.
\end{abstract}

\section{INTRODUCTION}

The effect of the carbonic anhydrase (EC 4.2.1.1) inhibitor, acetazolamide (Diamox), on cerebral blood flow $(\mathrm{CBF})^{1}$ has been studied by many investigators

Dr. Raichle is the recipient of Teacher-Investigator Award NS 11059 and GM 02016.

Received for publication 29 July 1977 and in revised form 21 April 1978.

${ }^{1}$ Abbreviations used in this paper: a-v, arterio-venous; $\mathrm{CBF}$, cerebral blood flow; $\mathrm{CMRO}_{2}$, cerebral metabolic rate for oxygen.
(1-7). All report that that intravenous administration of acetazolamide significantly increases CBF without affecting the cerebral metabolic rate for oxygen $\left(\mathrm{CMRO}_{2}\right)$. This reported increase in CBF cannot be entirely explained by the known hypercapnic effect of acetazolamide because the increase in CBF is not eliminated by controlling the arterial carbon dioxide tension. The results of these investigators are summarized in Table I.

We have reexamined the effect of acetazolamide on $\mathrm{CBF}$ and although we observed an increase, it was consistently less than the large increases in $\mathrm{CBF}$ others have reported (1-7). This apparent discrepancy prompted us to measure the effect of acetazolamide on the $\mathrm{CMRO}_{2}$ because the reported CBF changes after intravenous acetazolamide (Table I) are based, in large measure, on the use of the brain arteriovenous oxygen difference as an index of CBF. Such an approach to the measurement of CBF makes the important assumption that $\mathrm{CMRO}_{2}$ remains constant (8). The evidence that the $\mathrm{CMRO}_{2}$ is unaffected by intravenous acetazolamide is based on a single report (4). We observed a significant decrease in $\mathrm{CMRO}_{2}$ minutes after intravenous acetazolamide. This decrease in $\mathrm{CMRO}_{2}$, coupled with the modest but significant increase in CBF, we observe, is sufficient to explain most previous claims of a large increase in $\mathrm{CBF}$ estimated from brain arteriovenous oxygen differences. Further and more important, this observation suggests that the brain may be dependent to a greater extent than previously realized on erythrocyte carbonic anhydrase for adequate tissue oxygenation.

\section{METHODS}

Materials. Acetazolamide was obtained as Diamox from Lederle Laboratories, Div. of American Cyanamid Co., Pearl River, N. Y. The ${ }^{15} \mathrm{O}$-labeled $\mathrm{H}_{2} \mathrm{O}$ and ${ }^{15} \mathrm{O}$-labeled $\mathrm{O}_{2}$ used in these studies were prepared with the Washington University cyclotron according to procedures previously reported (9).

Experimental procedure. All the studies were performed on adult rhesus monkeys (Macaca mulatta). 
TABLE I

Reported Effect of Intravenous Acetazolamide on Cerebral Blood Flow

\begin{tabular}{|c|c|c|c|c|c|c|}
\hline Reference & Species & Anesthetic & CBF technique & $\begin{array}{l}\text { Acetazolamide } \\
\text { dose }\end{array}$ & $\begin{array}{l}\text { Con- } \\
\text { trolled } \\
\mathrm{PCO}_{2}\end{array}$ & CBF changes \\
\hline 1 & $\operatorname{dog}$ & pentobarbital & a-v $\mathrm{O}_{2}$ difference & $25 \mathrm{mg} / \mathrm{kg}$ & $\mathrm{PaCO}_{2}$ & $+55-69 \%$ \\
\hline 2 & human & none & a-v $\mathrm{O}_{2}$ difference & $1 \mathrm{~g}$ i.v. & $\mathrm{PaCO}_{2}$ & $\begin{array}{l}+66 \% \text { at } 30 \mathrm{~min} \\
+41 \% \text { at } 60 \mathrm{~min}\end{array}$ \\
\hline 3 & $\begin{array}{l}\text { dog } \\
\text { dog } \\
\text { human }\end{array}$ & $\begin{array}{l}\text { trichloroethylene } \\
\text { trichloroethylene } \\
\text { none }\end{array}$ & $\begin{array}{l}{ }^{85} \mathrm{Kr} \text { clearance } \\
\text { a-v } \mathrm{O}_{2} \text { difference } \\
\text { a-v } \mathrm{O}_{2} \text { difference }\end{array}$ & $\begin{array}{l}25 \mathrm{mg} / \mathrm{kg} \\
25 \mathrm{mg} / \mathrm{kg} \\
0.5 \mathrm{~g} \mathrm{i.v.}\end{array}$ & $\begin{array}{l}\mathrm{PtCO}_{2} \\
\mathrm{PtCO}_{2} \\
\mathrm{PaCO}_{2}\end{array}$ & $\begin{array}{l}+61 \% \\
+64 \% \\
+30 \%\end{array}$ \\
\hline 4 & human & none & $\mathrm{N}_{2} \mathrm{O}$ clearance & $0.5-2.0 \mathrm{~g}$ i.v. & No & $+62-87 \%$ \\
\hline 5 & $\begin{array}{l}\text { human } \\
\text { monkey } \\
\text { cat }\end{array}$ & $\begin{array}{l}\text { meperidine } \\
\text { ether or pentobarbital }\end{array}$ & $\begin{array}{l}\text { a-v } \mathrm{O}_{2} \text { difference } \\
\text { thermistor }\end{array}$ & $\begin{array}{l}0.5 \mathrm{~g} \text { i.v. } \\
15-25 \mathrm{mg} / \mathrm{kg} \\
250 \mathrm{mg} / \mathrm{kg}\end{array}$ & $\begin{array}{l}\text { No } \\
\text { No } \\
\text { No }\end{array}$ & $\begin{array}{l}+30 \% \\
\uparrow^{*} \\
\downarrow^{*}\end{array}$ \\
\hline 7 & $\begin{array}{l}\text { monkey } \\
\text { cat }\end{array}$ & ether & thermistor & $\begin{array}{l}15-25 \mathrm{mg} / \mathrm{kg} \\
500 \mathrm{mg}\end{array}$ & $\begin{array}{l}\text { No } \\
\text { No }\end{array}$ & $\begin{array}{l}\uparrow^{*} \\
\uparrow^{*} \downarrow\end{array}$ \\
\hline
\end{tabular}

* Actual change not specified.

$\ddagger \mathrm{CBF}$ increased only in association with an increase in arterial blood pressure.

CBF and $\mathrm{CMRO}_{2}$ were determined by following the washout of $\left[{ }^{15} \mathrm{O}\right] \mathrm{H}_{2} \mathrm{O}$ and $\left[{ }^{15} \mathrm{O}_{3} \mathrm{O}_{2}\right.$ injected into the right internal carotid artery as a small bolus $(0.25 \mathrm{ml})$ of the animal's blood labeled with one or the other radiopharmaceutical. To assure that the radioisotopes entered only the internal carotid artery, the right external carotid artery was ligated at the bifurcation of the common carotid artery at least $2 \mathrm{wk}$ before experimentation. The effect of such a surgical procedure on our experimental results is considered to be negligible. This matter has been dealt with in detail elsewhere (10).

For each experiment, the monkeys were anesthetized with phencyclidine ( $3 \mathrm{mg} / \mathrm{kg}$ Sernylan, Bio-Ceutic Laboratories, Inc., St. Joseph, Mo.), paralyzed with gallamine triethiodide /Flaxidyl, Davis-Geck, American Cyanamid Co., Pearl River, N. Y.), intubated with a cuffed endotracheal tube, and passively ventilated with an animal respirator (Harvard Apparatus Co., Inc., Millis, Mass.) on $100 \%$ oxygen. Gas mixtures of $5 \% \mathrm{CO}_{2}-95 \% \mathrm{O}_{2}$ or $10 \% \mathrm{CO}_{2}-90 \% \mathrm{O}_{2}$ were used in some experiments to establish control $\mathrm{PaCO}_{2}$ 's at higher levels. At least $20 \mathrm{~min}$ was allowed for the monkeys to stabilize on the new gas mixture before any measurements were made.

A 1.4-mm outside diameter catheter was inserted in the femoral artery, with its tip positioned in the right carotid artery under fluoroscopic guidance. To prevent clotting in this catheter system, which was used for the injection of radiopharmaceuticals, monitoring arterial blood pressure, and sampling arterial blood, all animals were anticoagulated with heparin at the beginning of the experiment. Arterial blood pressure, end-tidal $\mathrm{PCO}_{2}$, and rectal temperature were continuously monitored. Body temperature was kept around $37^{\circ} \mathrm{C}$ with a heating pad. Arterial $\mathrm{PCO}_{2}, \mathrm{pH}, \mathrm{PO}_{2}$, oxygen saturation, hematocrit, hemoglobin, and oxygen content were measured either shortly before or after each radiopharmaceutical injection. All blood gas samples were drawn in previously heparinized l-ml plastic syringes with the dead space filled with heparin. All blood gas data presented in this report were corrected for temperature deviations. Corrections for heparin dilution were unnecessary because the maximum dilution was $1: 24$. Corrections to the $\mathrm{PO}_{2}$ data for the "stirring effect" were unnecessary because the calibrating samples were subject to the same error.
$\mathrm{CBF}$ was determined by the injection of $\left[{ }^{15} \mathrm{O}\right] \mathrm{H}_{2} \mathrm{O}$ (11). An aliquot of the monkey's blood $\left(0.2-0.4 \mathrm{~cm}^{3}\right)$ containing the appropriate radiopharmaceutical was injected via the carotid artery catheter for each measurement. Typically, three or four control measurements were made within the hour preceding acetazolamide administration. The monkey would then be given a $30-\mathrm{mg} / \mathrm{kg}$ i.v. dose of acetazolamide and four or five more measurements of CBF would be made in the next 60$90 \mathrm{~min}$.

With a single administration of acetazolamide, measurements had to be done within 90 min because the effect of the drug on CBF and $\mathrm{CMRO}_{2}$ declined significantly after that time.

$\mathrm{CMRO}_{2}$ was measured by the paired injection of $\left[{ }^{15} \mathrm{O}\right] \mathrm{O}_{2}$ and $\left[{ }^{15} \mathrm{O}_{2} \mathrm{H}_{2} \mathrm{O}(12,13)\right.$. The sequence was as follows: an aliquot of $\mathrm{O}^{15} \mathrm{O}$-labeled blood was injected into the carotid artery; after allowing $35 \mathrm{~s}$ to follow the washout, an arterial blood gas sample was drawn. Typically, within 2-3 min of the $\left[{ }^{15} \mathrm{O}\right] \mathrm{O}_{2}$ injection, the radioactive background from the first injection was down to an acceptable level for the injection of the aliquot of $\left.{ }^{15} \mathrm{O}\right] \mathrm{H}_{2} \mathrm{O}$-labeled blood. All determinations of $\mathrm{CMRO}_{2}$ were run at $\mathrm{PaCO}_{2}$ levels in the range of 40-50 torr. As with the CBF alone, three or four control injection pairs were made before the administration of $30 \mathrm{mg} / \mathrm{kg}$ of acetazolamide, and four or five more paired injections afterward. The blood used for $\left[{ }^{15} \mathrm{O}\right] \mathrm{O}_{2}$ injections after acetazolamide administration also contained acetazolamide. This blood was obtained from the monkey after the drug had been administered. Thus, concentration of drug in the injected bolus was equal to that in the monkey.

Because carbonic anhydrase is carried in erythrocytes and not plasma, we thought it appropriate to qualitatively determine the effect of this partitioning on oxygen delivery to the brain. This question was approached by a triple injection procedure in three experiments run on two monkeys. Two of the injections were $\left[{ }^{15} \mathrm{O}\right] \mathrm{H}_{2} \mathrm{O}$ - and $\left[{ }^{15} \mathrm{O}\right] \mathrm{O}_{2}$-labeled normal monkey blood. The third injection was $\left[{ }^{15} \mathrm{O}\right] \mathrm{O}_{2}$-labeled blood that had been hemolyzed before labeling. In the first experiment, osmotic hemolysis was used; in the second and third, an ultrasonic probe (Artek Systems Corp., Farmingdale, N. Y.) was used to lyse the cells. All three injections were carried out 
within a 5-min period. As usual, three or four such injection sequences were done before drug administration and four or five after drug administration. Acetazolamide-containing blood, both normal and hemolyzed, was used for all $\left[{ }^{15} \mathrm{O}\right] \mathrm{O}_{2}$ injections after acetazolamide had been given to the monkey.

To assure ourselves that the brain oxygen extraction and, hence, $\mathrm{CMRO}_{2}$ measured by the oxygen-15 technique accurately reflected changes actually occurring under the peculiar circumstances of this experiment, we made a direct comparison of oxygen-15 extraction and the measured arteriovenous (a-v) difference in two studies. This was done in two monkeys that had specially designed Teflon (E. I. DuPont de Nemours \& Co., Wilmington, Del.) appliances (E. Koegel, San Antonio, Tex.) placed posteriorly in the calvaria over the superior sagittal sinus which allowed easy, repetitive sampling of mixed cerebral venous blood, and hence, direct determination of brain arteriovenous oxygen difference. We have found an excellent correlation between oxygen content of blood taken with this appliance from this site and jugular bulb oxygen content in the rhesus monkey, directly supporting the contention that this represents cerebralmixed venous blood. ${ }^{2}$

Monkeys used for more than one experiment were allowed to recuperate for a minimum of $2 \mathrm{wk}$ between procedures.

Radioisotope detection and data collection. The washout of the radioisotopes was followed with a single $3 \times 2$ inch $\mathrm{NaI}$ (Tl) scintillation detector collimated and placed to assure uniform detection of the right cerebral hemisphere. The signal from the detector was fed into a LINC laboratory minicomputer (Digital Equipment Corp., Maynard, Mass.) for data storage and analysis.

Data analysis. The details of the data analysis are completely described elsewhere (10-13) and will not be repeated here. In general, each injection of a labeled compound allows us to compute the extraction fraction of that compound, i.e., that percentage of the compound which is extracted from the injection bolus on a single pass through the brain. In addition, the rate of washout of $\left[{ }^{15} \mathrm{O}\right] \mathrm{H}_{2} \mathrm{O}$ allows computation of $\mathrm{CBF}$ in milliliters per minute per $100 \mathrm{~g}$ tissue (11). The cerebral metabolic rate for oxygen is given by the extraction fraction of oxygen times cerebral blood flow times arterial oxygen content. Experimental justification for these methods has been previously published $(11-13)$.

\section{RESULTS}

Effect of acetazolamide on CBF. 22 experiments were performed on 12 monkeys. 2 experiments were rejected. In both cases there was no net increase in CBF after acetazolamide administration, even though there was a significant increase in $\mathrm{PaCO}_{2}$. Furthermore, considering the $\mathrm{PaCO}_{2}$ levels, baseline CBF was depressed in these animals, suggesting that the normal reactivity of the cerebral vasculature was impaired in these animals. Thus, there are 79 control and $97 \mathrm{ex}-$ perimental data points (Fig. 1).

Fig. 1 shows the relationship between $\mathrm{CBF}$ and $\mathrm{PaCO}_{2}$ for the control (predrug) and experimental populations. Control $\mathrm{PaCO}_{2}$ was varied over the range shown by mild hypo- or hyperventilation and (or) ventilation with gas mixtures containing 5 or $10 \%$ carbon dioxide balanced with oxygen. The equations for the regression lines and 95\% confidence intervals of the slopes and intercepts

\footnotetext{
${ }^{2}$ Raichle, M. E. Unpublished observations.
}

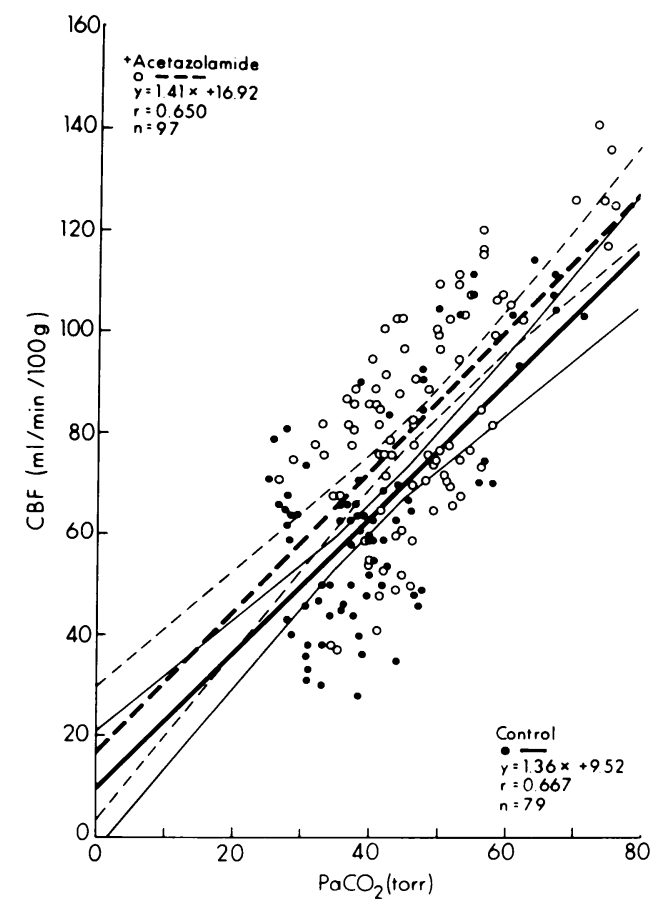

Figure 1 Relationship between $\mathrm{PaCO}_{2}$ and the CBF before (solid lines) and after (broken lines) the intravenous administration of $30 \mathrm{mg} / \mathrm{kg}$ acetazolamide to the rhesus monkeys. The $95 \%$ confidence limits are shown for each line.

are: Control: $\mathrm{CBF}=9.52( \pm 12.1)+1.36( \pm 0.30) \mathrm{PaCO}_{2}$. Experimental: $\quad \mathrm{CBF}=16.92( \pm 13.6)+1.41 \quad( \pm 0.28)$ $\mathrm{PaCO}_{2}$. The means for the two lines are: Control: $\overline{\mathrm{CBF}}=64.7 \mathrm{ml} / \mathrm{min}$ per $100 \mathrm{~g}, \overline{\mathrm{PaCO}}_{2}=40.7$ torr. Experimental: $\overline{\mathrm{CBF}}=83.8 \mathrm{ml} / \mathrm{min}$ per $100 \mathrm{~g}, \overline{\mathrm{PaCO}}_{2}$ $=47.5$ torr. Fig. 2 shows the absolute increase of $\mathrm{CBF}$

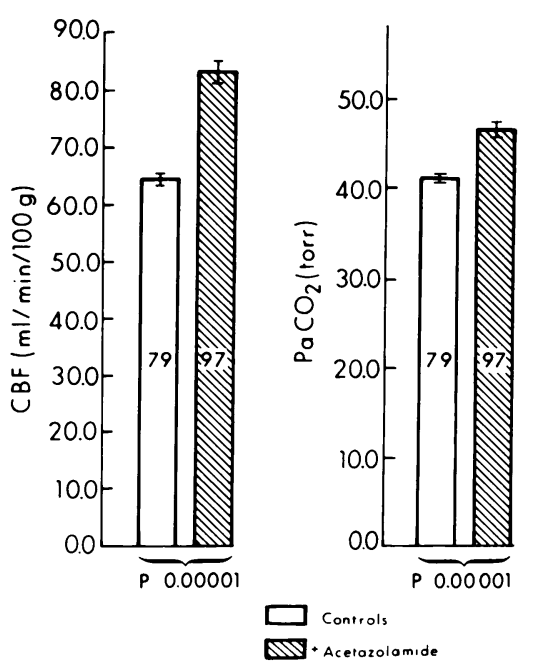

Figure 2 The change in mean CBF and mean $\mathrm{PaCO}_{2}$ after intravenous administration of acetazolamide in rhesus monkeys. The mean control CBF was $64.7 \mathrm{ml} / \mathrm{min}$ per $100 \mathrm{~g}$ and the mean control $\mathrm{PaCO}_{2}$ was 40.7 torr. The number of data points are shown on the bars. The error bars $=2 \mathrm{SEM}$. 
and $\mathrm{PaCO}_{2}$ after acetazolamide. There is a mean increase of $29.2 \%$ in $\mathrm{CBF}$ and $13.3 \%$ in $\mathrm{PaCO}_{2}$. On the basis of a paired $t$ test, these increases are significant ( $P<0.000001$ for both). This poses a question: how much of the CBF increase is due to increased $\mathrm{PaCO}_{2}$, and how much is due to other, not understood, effects of acetazolamide on CBF? Work by others (1-3) would suggest that the observed increase in CBF cannot be entirely explained by the increase in $\mathrm{PaCO}_{2}$.

To determine how much of the increase in CBF we observed was due to the increase in $\mathrm{PaCO}_{2}$, it was necessary to statistically compare the two regression lines shown in Fig. 1. The usual statistical techniques to compare regression lines cannot be used in this case because the two populations are not independent of each other. The animals used to create the first sample (controls) were also used for the second (experimentals). A technique for comparing such correlated regression lines has recently been developed by the Washington University Medical School Biostatistics Division. ${ }^{3}$ To make use of this technique, the data must be in a paired (i.e., before and after) format. Thus the control and experimental data points were averaged for each run. These were analyzed to give two regression lines, each made up of 20 points. The equations of the regression lines are: Control: $\mathrm{CBF}=2.24+1.51 \mathrm{PaCO}_{2}$. Experimental: $\mathrm{CBF}=16.25+1.38 \mathrm{PaCO}_{2}$. The first step in the actual statistical analysis was a multiple linear regression of $\left(\overline{\mathrm{CBF}}_{c}-\overline{\mathrm{CBF}}_{e}\right)$ on $\left(\overline{\mathrm{PaCO}}_{2}\right)_{c}$ and $\left(\overline{\mathrm{PaCO}}_{2}\right)_{e}$, where subscript $c$ refers to control data and $e$ to experimental data. The resulting equation has the form: $\left(\overline{\mathrm{CBF}}_{c}-\overline{\mathrm{CBF}}_{e}\right)_{i}=a_{1}+b_{1}\left(\overline{\mathrm{PaCO}}_{2}\right)_{c \mathrm{i}}$ $+b_{2}\left(-\overline{\mathrm{PaCO}}_{2}\right)_{e \mathrm{i}}\left(i=1,2, \ldots, 20\right.$ and $a_{1}=4.102$, $b_{1}=0.812$ and $\left.b_{2}=1.160\right)$. Substituting the mean control value of $\mathrm{PaCO}_{2}=40.7$ torr for $\left(\mathrm{PaCO}_{2}\right)_{c}$ and $\left(\mathrm{PaCO}_{2}\right)_{e}$ yields a weighted average increase in CBF of $10.1 \mathrm{ml} / \mathrm{min}$ per $100 \mathrm{~g}$ above the mean control $\mathrm{CBF}=64.7 \mathrm{ml} / \mathrm{min}$ per $100 \mathrm{~g}$, when there is no change in $\mathrm{PaCO}_{2}$. This would suggest that less than one-half of the observed increase in CBF (Fig. 2) can be directly attributed to the hypercapnic effect of acetazolamide. This statement is only valid if the two regression lines are parallel and the vertical displacement between them is significant. This statistical procedure tests the slopes and intercepts separately. For the given data set, there is no significant difference between either the slopes or the intercepts $(P>0.30$ and $P>0.60$, respectively). The procedure then allows a test to see if the regression lines are concurrent. Here, there is a significant difference (level of $F$ statistic $=7.02$; statistical degrees of freedom $=2,17 ; P<0.001)$. Hence, whereas the two regression lines are parallel, the vertical displacement between them is significant. This means that a significant increase in CBF has occurred

\footnotetext{
${ }^{3}$ Choi, S. Unpublished observations.
}

independent of the change in $\mathrm{PaCO}_{2}$. This is in agreement with the work of others $(1-3)$ who reached a similar conclusion based on actual experimental manipulation of the arterial carbon dioxide tension.

Effect of acetazolamide on brain $a-v$ oxygen difference. Two experiments were run on two monkeys to determine the effect of acetazolamide on cerebral a-v $\mathrm{O}_{2}$ differences. Because our technique for measuring the extraction of oxygen by the brain using oxygen-15 $(12,13)$ is different from that normally employed (i.e., direct measurement of cerebral a-v oxygen content) we felt obliged to demonstrate, in addition, that our results were not peculiar to our technique under the circumstances of this experiment.

The a-v extraction was computed from the measured blood oxygen contents according to the formula: a-v extraction $=\left(\right.$ arterial $\mathrm{O}_{2}$ content - venous $\mathrm{O}_{2}$ content $) /$ (arterial $\mathrm{O}_{2}$ content). The computation of the a-v extraction using externally monitored oxygen-15 has been previously described and validated $(12,13)$.

The data we obtained using both the oxygen-15 method and direct measurement are shown in Fig. 3. The mean control a-v $\mathrm{O}_{2}$ extraction was 0.434 . Using a paired $t$ test to compare the results given by the two techniques shows that there is no significant difference between the techniques $(P>0.33)$. Likewise, there is no difference between the techniques after acetazolamide administration $(P>0.46)$.

After acetazolamide, the arterial oxygen content did not change, but the venous oxygen content increased.

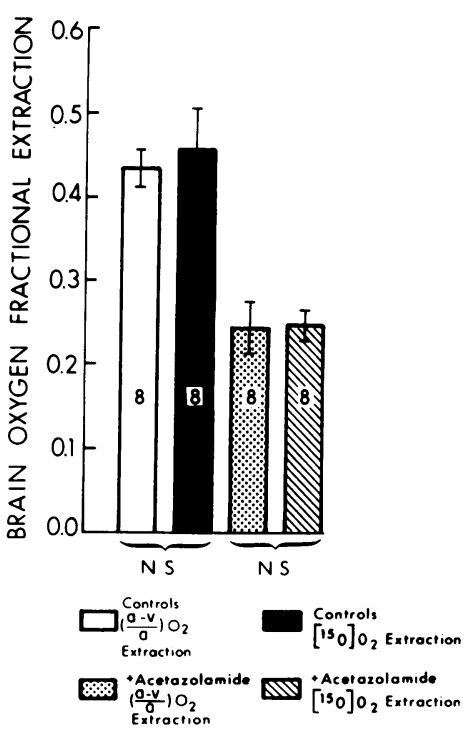

FIGURE 3 A comparison of the brain oxygen/fractional extraction as determined by the direct measurement of the brain a-v oxygen content difference (a-v/a extraction) and externally monitored oxygen-15-labeled hemoglobin $\left(\left[{ }^{15} \mathrm{O}\right] \mathrm{O}_{2}\right.$ extraction) before and after the intravenous administration of acetazolamide to rhesus monkeys. 
The resulting a-v oxygen difference is $56.5 \%$ of control, which is a significant difference $(P<0.00001)$. Using this as an indicator of a change in $\mathrm{CBF}$, as several investigators have done (see Table I), would imply a $77 \%$ increase in $\mathrm{CBF}(1 / 0.565=177 \%)$, assuming that there was no change in the $\mathrm{CMRO}_{2}$ and remembering that $\mathrm{PaCO}_{2}$ was uncontrolled. It is clear from our data, however, that $\mathrm{CMRO}_{2}$ changed.

Effect of acetazolamide on $\mathrm{CMRO}_{2} .12$ experiments run on 8 monkeys resulted in 45 control data points and 24 experimental data points. The data are presented in Fig. 4. The mean control $\mathrm{CMRO}_{2}$ before normalization was $4.16 \mathrm{ml} / \mathrm{min}$ per $100 \mathrm{~g}$. After acetazolamide, the $\mathrm{CMRO}_{2}$ dropped to $67.8 \%$ of control. A paired $t$ test shows this decrease to be significant $(P<0.00001)$.

Effect of hemolysis on $\mathrm{CMRO}_{2}$. To determine the effect of confinement of carbonic anhydrase to the erythrocyte in circulating blood on oxygen delivery to the brain, we performed three additional experiments on two monkeys. The results are shown in Fig. 5. A paired $t$ test shows that there was a significant difference between the control $\mathrm{CMRO}_{2}$ obtained with normal blood and the control $\mathrm{CMRO}_{2}$ obtained with hemolyzed blood $(4.14$ and $4.50 \mathrm{ml} / \mathrm{min}$ per $100 \mathrm{~g}$, respectively, $P<0.0067)$. However, there was no significant difference between the mean $\mathrm{CMRO}_{2}$ 's obtained after acetazolamide with normal and hemolyzed blood (2.99 and $2.96 \mathrm{ml} / \mathrm{min}$ per $100 \mathrm{~g}$, respectively, $P>0.33$ ). The overall drop in $\mathrm{CMRO}_{2}$ is of course similar to that obtained in the preceding nine experiments (Fig. 4).

\section{DISCUSSION}

Our data show that the intravenous administration of acetazolamide sufficient to acutely inhibit all circulat-

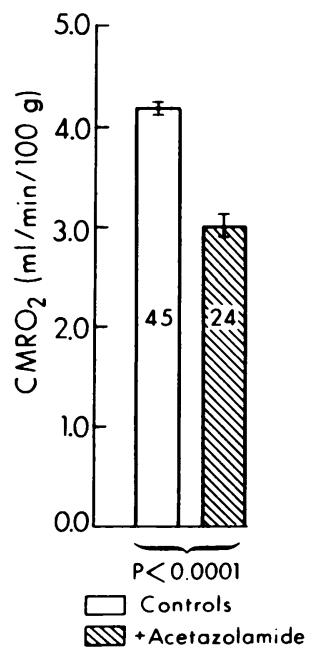

FIGURE 4 The effect of intravenous administration acetazolamide on $\mathrm{CMRO}_{2}$. The mean control $\mathrm{CMRO}_{2}$ was $4.16 \mathrm{ml} / \mathrm{min}$ per $100 \mathrm{~g}$.

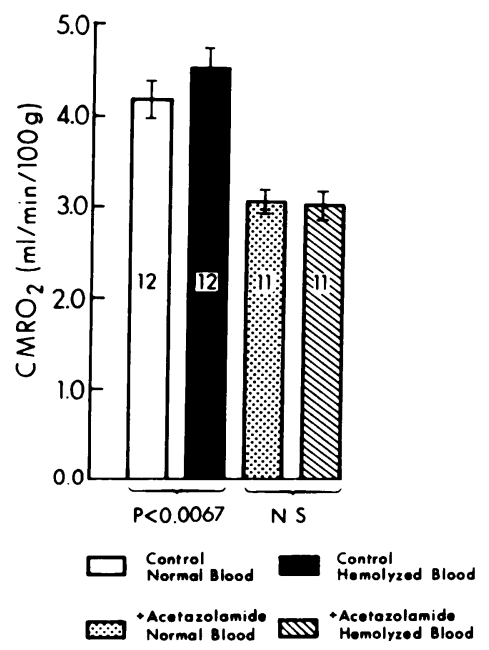

Figure 5 The effect of hemolysis of the oxygen-15-labeled blood used to measure the $\mathrm{CMRO}_{2}$ before (control) and after the intravenous administration of acetazolamide to rhesus monkeys. The mean control $\mathrm{CMRO}_{2}$ obtained with nonhemolyzed blood was $4.14 \mathrm{ml} / \mathrm{min}$ per $100 \mathrm{~g}$.

ing carbonic anhydrase increases CBF $29.2 \%$. This increase in CBF is accompanied by a significant increase in arterial carbon dioxide tension. This increase in $\mathrm{PaCO}_{2}$ is well known to occur with acetazolamide because of the effect of this drug on slowing the conversion of $\mathrm{HCO}_{3}^{-}$to diffusible $\mathrm{CO}_{2}$ in the lung capillaries (14). The most obvious indication of this during our experiments was an immediate fall in end-tidal $\mathrm{PCO}_{2}$ to $\cong 50 \%$ of normal after acetazolamide administration.

Both our work and that of others (Table I, 1-3) suggest the acetazolamide-induced hypercapnia is only partly responsible for the increase in CBF observed. Statistical correction of our CBF data for the $\mathrm{PaCO}_{2}$ increase reduces the observed $\mathrm{CBF}$ increase from 29.2 to $15.4 \%$. We may well be overestimating the effect of $\mathrm{PaCO}_{2}$ in our data due to the difficulties in measuring $\mathrm{PaCO}_{2}$ after the administration of acetazolamide $(14,15)$. When an arterial sample is drawn, there is a relative excess of $\mathrm{HCO}_{3}^{-}$. In the time required to measure $\mathrm{PaCO}_{2}$, some of the $\mathrm{HCO}_{3}^{-}$converts to $\mathrm{CO}_{2}$ causing the measured $\mathrm{PaCO}_{2}$ to be slightly high. Thus all the points on the experimental curve of Fig. 1 should probably be shifted slightly to the left. This would mean that slightly less of the CBF increase can probably be attributed to the increased $\mathrm{PaCO}_{2}$ than our data actually predict. We plan to investigate the magnitude of this error in the future, but we do not expect it to be large.

Our data for the relationship between CBF and $\mathrm{PaCO}_{2}$, both before and after acetazolamide administration (Fig. 1) is in good agreement with previous data, over the range of $\mathrm{PaCO}_{2}$ studied $(16,17)$.

In contrast to our findings, previous investigators (Table I) have reported up to $87 \%$ increases in CBF 
after acetazolamide administration, even when $\mathrm{PaCO}_{2}$ has reportedly been controlled. Differences in species, level and type of anesthesia, and dose and time of administration of acetazolamide between these studies and ours make the discrepancy between our smaller $\mathrm{CBF}$ increase and those reported difficult to resolve. We would like to point out though, that some investigators used the brain a-v $\mathrm{O}_{2}$ content difference to estimate $\mathrm{CBF}$. This technique is only valid if there is no change in cerebral oxygen metabolism (8). Before our study, Posner and Plum (4) published the only data on the effect of acetazolamide on $\mathrm{CMRO}_{2}$. Other investigators, in turn, used their study to justify the use of brain a-v $\mathrm{O}_{2}$ content difference to estimate change in $\mathrm{CBF}$ because Posner and Plum reported no significant effect on $\mathrm{CMRO}_{2}$ by acetazolamide. However, their study used only five "normal" control patients, and of these one had previous brain damage and four had arteriosclerosis. Furthermore, these investigators did see a significant drop in $\mathrm{CMRO}_{2}$ in four patients with hepatic encephalopathy (4). We must conclude, therefore, that a failure to appreciate a significant drop in $\mathrm{CMRO}_{2}$ led many (Table I) to an overestimation of the CBF increase produced by the intravenous administration of acetazolamide.

Our study suggests that intravenous acetazolamide in healthy, lightly anesthetized rhesus monkeys produces a $32 \%$ reduction in $\mathrm{CMRO}_{2}$. This effect occurs within minutes of acetazolamide administration, which is consistent with the $3 \mathrm{~min}$ in vitro equilibration time between erythrocytic carbonic anhydrase and acetazolamide reported by Maren et al. (18). Furthermore, these data suggest that the effect may, in fact, be primarily achieved through an effect of acetazolamide on the erythrocytic carbonic anhydrase, because it is unlikely that a significant amount of the drug can cross the bloodbrain barrier in this time. This is supported by the observation of Roth et al. (19) who have reported that the entry of $\left[{ }^{35}\right.$ S ]acetazolamide into cat brain has a time course in hours at a dosage level of $150 \mathrm{mg} / \mathrm{kg}$. We are currently carrying out studies to clarify the rate of tritiated acetazolamide into rat brain. Preliminary results (unpublished) are in agreement with those of Roth et al. (19), and suggest that little, if any, acetazolamide is likely to have entered the brain at a time when we observe a significant fall in $\mathrm{CMRO}_{2}$.

If the acetazolamide effect on $\mathrm{CMRO}_{2}$ is localized to the blood, what is its mechanism? As has been previously suggested by Cotev et al. (1), carbonic anhydrase inhibition should interfere with the Bohr shift, the mechanism that augments $\mathrm{O}_{2}$ release from hemoglobin via an acidic $\mathrm{pH}$ shift (20). Normally as the oxygencarrying erythrocytes enter the capillaries, $\mathrm{CO}_{2}$ diffuses in and is virtually instantaneously converted to $\mathrm{H}^{+}$and $\mathrm{HCO}_{3}^{-}$by carbonic anhydrase. When the carbonic anhydrase is inhibited by acetazolamide (inhibition should be $>99.99 \%$ at $30 \mathrm{mg} / \mathrm{kg}$ ) (21), $\mathrm{CO}_{2}$ cannot convert to $\mathrm{H}^{+}$and $\mathrm{HCO}_{3}^{-}$before the blood has left the capillary, thus the Bohr shift does not occur and oxygen unloading is inhibited.

The hypothesis that inhibition of erythrocyte carbonic anhydrase with delayed hydration of carbon dioxide and prevention of the Bohr effect poses a significant limitation on oxygen delivery to brain is supported by two findings in our study. First, $\mathrm{CMRO}_{2}$ measured with hemolyzed blood was $9 \%$ higher than that measured with normal blood without any carbonic anhydrase inhibition (Fig. 5).

Second, after acetazolamide was given, there was no significant difference between the $\mathrm{CMRO}_{2}$ measured with hemolyzed and normal blood. We believe these data can be interpreted in the following way. In the hemolyzed blood, carbon dioxide only had to cross the vascular endothelium to achieve immediate access to erythrocyte carbonic anhydrase which was free in plasma. Thus, the time course of the Bohr effect was speeded up and oxygen delivery to the tissue improved. After acetazolamide was given, the presence of carbonic anhydrase and hemoglobin free in the plasma made no difference because the enzyme was inhibited and, thus, once the $\mathrm{CO}_{2}$ crossed the capillary endothelium it still did not have enough time to be hydrated before it left the capillary. It must be emphasized that what is occurring is not due to a change in arterial hemoglobin saturation (which was always $100 \%$ ), but to a change in the unloading of oxygen from hemoglobin. This phenomena could not be reproduced by altering inspired gas $\mathrm{O}_{2}$ content.

The increase in $\mathrm{CMRO}_{2}$ seen with hemolyzed blood without acetazolamide might easily be attributed to factor(s) other than carbonic anhydrase released by hemolysis from erythrocytes, leukocytes, and platelets. However, after acetazolamide was given, the $\mathrm{CMRO}_{2}$ was identical in both normal and hemolyzed blood and significantly depressed from the control level (Fig. 5). It is well established that the only effect of acetazolamide is to inhibit carbonic anhydrase (22). If some factor other than carbonic anhydrase released by hemolysis caused the increase in $\mathrm{CMRO}_{2}$, before acetazolamide, it should have caused a similar increase after acetazolamide, which did not occur. To confirm this, studies are currently underway in which bovine carbonic anhydrase is added to whole monkey blood. Preliminary results support those obtained with hemolyzed monkey blood.

An alternative explanation for this observation is that erythrocyte carbonic anhydrase, particularly isoenzyme $B$, may be more active when released into the extracellular fluid (i.e., plasma) environment by lysis (23), thus, actually speeding up the hydration of carbon dioxide. Neither this explanation nor the one we offer would be inconsistent with our hypothesis. 
These data support the hypothesis that erythrocyte carbonic anhydrase is important for oxygen delivery to brain tissue. These observations are in accord with the critical nature of the temporal and spatial relationships existing in the microvasculature for erythrocyte carbonic anhydrase as previously emphasized by the work of Forster and Crandall (24).

Actual measurements of cortical surface $\mathrm{PO}_{2}$ after acetazolamide administration have shown an apparent increase in tissue $\mathrm{Po}_{2}$ and suggested $(1,3,6,7)$ that tissue oxygenation is quite adequate. We would point out, however, that tissue $\mathrm{PO}_{2}$ was measured using an oxygen electrode placed directly on the cortical surface. An electrode so placed would not only look at brain tissue $\mathrm{PO}_{2}$, but also at the $\mathrm{PO}_{2}$ of any blood vessels near the electrode. There is a relatively higher concentration of veins and venules at the cortical surface, with arteries and arterioles tending to run deeper (25). Thus the $\mathrm{PO}_{2}$ electrode would undoubtedly reflect the increased $\mathrm{P}_{\mathrm{v}} \mathrm{O}_{2}$ caused by the delayed $\mathrm{Bohr}$ shift as expained above. We predict that the actual tissue $\mathrm{PO}_{2}$ should fall.

The drop in $\mathrm{CMRO}_{2}$ we observe may provide an explanation for the $15.4 \%$ increase in CBF that cannot be explained by the acetazolamide-induced hypercapnia. There is evidence that a decreased $\mathrm{PO}_{2}$ causes an increase in CBF (26-28). Grote et al. (29), in particular, state that $\mathrm{CBF}$ is even more sensitive to hypoxia during respiratory acidosis which of course exists during carbonic anhydrase inhibition. If tissue hypoxia does, in fact, exist after acetazolamide administration due to an interference with oxygen unloading in brain capillaries, then an increase in CBF might well be anticipated. We appreciate, however, that on the basis of data from other laboratories (26-29), tissue hypoxia sufficient to produce a $15 \%$ increase in CBF is not usually accompanied by a reduction in $\mathrm{CMRO}_{2}$. This suggests that the relationship between $\mathrm{CMRO}_{2}, \mathrm{CBF}$, and tissue oxygen availability may be different under the circumstances of our experiment or, alternatively, that the factor(s) responsible for the flow increase we observe is not related to hypoxia. One important difference between our experiment and those of others concerns the means by which tissue hypoxia is achieved. As far as we have been able to determine, all reported experiments on the effect of hypoxia on CBF have been achieved by reducing the oxygen content of an inspired gas mixture. This stimulus not only reduces tissue $\mathrm{PO}_{2}$, but also directly reduces the oxygen tension of the vascular smooth muscle in parallel with the reduction in the arterial oxygen tension $\left(\mathrm{PaO}_{2}\right)$. Because vascular smooth muscle is known to relax under the influence of hypoxia (30), part of the increase in CBF in these studies might be mediated by a direct response of the smooth muscle to hypoxia. With intravenous acetazolamide, the $\mathrm{PaO}_{2}$ is not reduced, hence, a possible direct effect of hypoxia on the vascular smooth muscle may be averted. Changes in cerebrovascular resistance now must occur secondary to metabolic changes occurring within brain tissue. That such changes might have a less profound effect on cerebral circulation than previously appreciated should not be too surprising when it is realized that a substantial part of the blood flow resistance in the circulation of the cerebral cortex is not enclosed in the cerebral tissue $(31,32)$. Thus, a large part of flow resistance cannot be adjusted acutely by a direct influence of metabolites on the vascular smooth muscle (31-33).

It seems reasonable to suggest as a working hypothesis that acetazolamide may induce a critical reduction in tissue oxygen availability which is only partly compensated for by an increase in CBF. Further, the normal response of the cerebrovasculature to hypoxia is attenuated under these circumstances because the $\mathrm{PO}_{2}$ remains normal in the smooth muscle of a significant portion of the cerebral resistance vasculature. Further work is clearly needed in this area.

Finally, the possibility that acetazolamide may reduce $\mathrm{CMRO}_{2}$ by interfering with the oxygen unloading in the microvasculature must, if substantiated, be taken into consideration in the clinical use of the drug. Thus, its use in conditions such as epilepsy, where oxygen delivery to the tissue may at times become critical (33), may need to be reconsidered.

\section{ACKNOWLEDGMENTS}

The authors wish to thank Ms. Christa Cooper, Mr. Robert Feldhaus, Mr. John Mazanec, and the staff of the Washington University Medical School Cyclotron for technical assistance. We wish to thank Dr. S. Choi of the Division of Biostatistics, Department of Preventive Medicine, Washington University Medical School for assistance in the statistical analysis of our data.

This work was supported by National Institutes of Health grants Hl13851 and PSO 6833.

\section{REFERENCES}

1. Cotev, S., J. Lee, and J. W. Severinghaus. 1968. The effects of acetazolamide on cerebral blood flow and cerebral tissue $\mathrm{pO}_{2}$. Anesthesiology. 29: 471-477.

2. Ehrenreich, D. L., R. A. Burns, R. W. Alman, and J. F. Fazekas. 1961. Influence of acetazolamide on cerebral blood flow. Arch. Neurol. 5: 125-130.

3. Severinghaus, J. W., and S. Cotev. 1968. Carbonic acidosis and cerebral vasodialation after diamox. Scand. J. Clin. Lab. Invest. 1(Suppl. 102): E.

4. Posner, J. B., and F. Plum. 1960. The toxic effects of carbon dioxide and acetazolamide in hepatic encephalopathy. J. Clin. Invest. 39: 1246-1258.

5. Gotoh, F., J. S. Meyer, and M. Tomita. 1966. Carbonic anhydrase inhibition and cerebral venous blood gases and ions in man. Arch. Intern. Med. 117: 39-46.

6. Meyer, J. S., F. Gotoh, and Y. Tazaki. 1961. Inhibitory action of carbon dioxide and acetazolamide in seizure activity. Electroencephalogr. Clin. Neurophysiol. 13: 762-775. 
7. Meyer, J. S., and F. Gotoh. 1961. Interaction of cerebral hemodynamics and metabolism. Neurology. 11: 46-65.

8. Shapiro, W., A. J. Wasserman, and J. L. Patterson. 1965. Human cerebrovascular response time to elevation in arterial carbon dioxide tension. Arch. Neurol. 13: 130138.

9. Welch, M. J., and M. M. Ter-Pogossigan. 1968. Preparation of short half-lived radioactive gases for medical studies. Radiat. Res. 36: 580-587.

10. Raichle, M. E., J. O. Eichling, M. G. Straatmann, M. J. Welch, K. B. Larson, and M. M. Ter-Pogossian. 1976. Blood-brain barrier permeability of ${ }^{11} \mathrm{C}$-labeled alcohols and ${ }^{15} \mathrm{O}$-labeled water. Am. J. Physiol. 230: 543-552.

11. Eichling, J. O., M. E. Raichle, R. L. Grubb, and M. M. Ter-Pogossian. 1974. Evidence of the limitations of water as a freely diffusible tracer in brain of the rhesus monkey. Circ. Res. 35: 358-364.

12. Ter-Pogossian, M. M., J. O. Eichling, D. O. Davis, and M. J. Welch. 1970. The measure in vivo of regional cerebral oxygen utilization by means of oxyhemoglobin labeled with radioactive oxygen-15. J. Clin. Invest. 49: 381-391.

13. Raichle, M. E., R. L. Grubb, J. O. Eichling, and M. M. Ter-Pogossian. 1976. Measurement of brain oxygen utilization with radioactive oxygen-15: experimental verification. J. Appl. Physiol. 40: 638-640.

14. Mithoefer, J. C. 1959. Inhibition of carbonic anhydrase: its effect on carbon dioxide elimination by the lungs. $J$. Appl. Physiol. 14: 109-115.

15. Brzezinski, J., A. Kjällquist, and B. K. Siesjö. 1967. Mean carbon dioxide tension in the brain after carbonic anhydrase inhibition. J. Physiol. (Lond.). 188: 13-23.

16. Grubb, R. L., M. E. Raichle, J. O. Eichling, and M. M. Ter-Pogossian. 1974. The effects of changes in $\mathrm{PaCO}_{2}$ on cerebral blood volume, blood flow, and vascular mean transit time. Stroke. 5: 630-639.

17. Reivich, M. 1964. Arterial $\mathrm{pCO}_{2}$ and cerebral hemodynamics. Am. J. Physiol. 206: 25-35.

18. Maren, T. H., A. L. Parcell, and M. N. Malik. 1960. A kinetic analysis of carbonic anhydrase inhibition.J. Pharmacol. Exp. Ther. 130: 389-400.

19. Roth, L. J., J. C. Schoolar, and C. F. Barlow. 1959. Sulfur35 labeled acetazolamide in cat brain. J. Pharmacol. Exp. Ther. 125: 128-136.

20. Bohr. C., K. A. Hasselbalch, and A. Krogh. 1904. Über einen in biologischer Beziehung wichtigen Einfluss, den die Kohlensaurespannung des Blutes auf dessen Sauerstoffbindung übt. Skand. Arch. Physiol. 16: 402.

21. Maren, T. H. 1977. Use of inhibitors in physiological studies of carbonic anhydrase. Am. J. Physiol. 232(4): F291-F297.

22. Maren, T. H. 1967. Carbonic anhydrase: chemistry, physiology, and inhibition. Physiol. Rev. 47(4): 595-781.

23. Itada, N., and R. E. Forster. 1977. Carbonic anhydrase activity in intact red blood cells measured with ${ }^{18} \mathrm{O}$ exchange. J. Biol. Chem. 252: 3881-3890.

24. Forster, R. E., and E. D. Crandall. 1975. Time course of exchanges between red cells and extracellular fluid during $\mathrm{CO}_{2}$ uptake. J. Appl. Physiol. 38: 710-718.

25. Kaplan, H. A., and D. H. Ford. 1966. The Brain Vascular System. Elsevier North-Holland, Inc., New York. 95-104.

26. Cohen, P. J., S. C. Alexander, T. C. Smith, M. Reivich, and H. Wollman. 1967. Effects of hypoxia and normocarbia on cerebral blood flow and metabolism in conscious man. J. Appl. Physiol. 23: 183-189.

27. Kogure, K., P. Scheinberg, O. M. Reinsmuth, M. Fujishima, and R. Busto. 1970. Mechanisms of cerebral vasodilation in hypoxia. J. Appl. Physiol. 29: 223-229.

28. Johannsson, H., and B. K. Siesjo. 1974. Blood flow and oxygen consumption of the rat brain in profound hypoxia. Acta Physiol. Scand. 90: 281-282.

29. Grote, J., H. Kreuscher, R. Schubert, and H. J. Russ. 1970. Investigations on the influence of $\mathrm{PaO}_{2}$ and $\mathrm{PaCO}_{2}$ on the regulation of cerebral blood flow in dogs. Proceedings of the 4th International Symposium on Regulation of CBF. London. 200-204.

30. Detar, R., and D. F. Bohr. 1968. Oxygen and vascular smooth muscle contraction. Am. J. Physiol. 214: 241-244.

31. Shapiro, H. M., D. D. Stromberg, D. R. Lee, and C. A. Wiederhelm. 1971. Dynamic pressures in the pial arterial microcirculation. Am. J. Physiol. 221: 279-283.

32. Kanzow, E. and D. Dieckhoff. 1969. On the location of vascular resistance in the cerebral circulation. In Cerebral Blood Flow. M. Brock, C. Fieschi, D. H. Ingvar, N. A. Lassen, and K. Schurmann, editors. Springer-Verlag, New York, Inc., New York, 96-97.

33. Howse, D. C., J. J. Coronna, T. E. Duffy, and F. Plum. 1974. Cerebral energy metabolism, $\mathrm{pH}$ and blood flow during seizures in the cat. Am. J. Physiol. 227: 14441451 . 